Scientists dispute wisdom of Canada reopening fishery

[MONTREAL] Canadian scientists are divided over the government's announcement last week that it is partially to reopen the east coast cod fishery, closed in 1992 because of declining stocks.

Some are openly critical of the decision. Ransom Myers, professor of ocean studies at Dalhousie University in Halifax, Nova Scotia, says stocks remain at a very low level. Myers, who until recently was employed by the federal department of fisheries and oceans, argues that the fisheries minister was not sufficiently informed of the risks to long-term fishing prospects in the region. Jeffery Hutchings, also of Dalhousie, describes the move as "a management decision inconsistent with the best stock analysis that scientists put forth".

But William Doubleday, director-general of science for the fisheries department, says that "there are considerable uncertainties about abundances", and that scientists disagree about the risks of reopening the fishery. He agrees that stocks remain at low levels and that the scientific data have remained unchanged sincelast June, however. He denies the decision is related to the timing of the forthcoming federal elections.

The reopening of the fishery will allow 10,000 tonnes of cod to be taken off the southern coast of Newfoundland, compared to about 35,000 tonnes when it was closed in 1992. In the northern Gulf of St Lawrence, 6,000 tonnes will be allowed, rather than the former 40,000. And the sentinel fishery, at 2,000 tonnes, will be allowed to monitor changes in the southern gulf.

The government's move is based on recommendations of the Fisheries Conservation Resource Council, an independent body of fishing industry representatives, scientists and other interested parties. According to Doubleday, the main reason for limited reopening is to obtain information to provide a better basis for a long-term decision.

The new limits are quite low compared to historic levels - about one-third of the catch taken when the fishery was closed, and less than a quarter of what it was in previous years. "So the scientific view is that this doesn't pose any significant conservation risk to the stocks and it's an opportunity to get better information about them," says Doubleday.

Extensive discussions took place with fishermen about how they would catch their quota responsibly, from the point of view of conservation.

The new quotas are for this year only, says Doubleday. The stock will be assessed next January, taking into account a new scientific survey, a further sentinel review and the results of this year's fishing. DavidSpurgeon

\title{
Accident fall-out threatens Japan's nuclear company
}

[TOKYO] Japan's Power Reactor and Nuclear Fuel Development Corporation (PNC) is threatened with drastic reform - and perhaps even dissolution - after a series of accidents and cover-ups at nuclear facilities. PNC is a huge semi-public organization responsible for a large portion of Japan's research and development on nuclear power.

The Science and Technology Agency (STA), which oversees PNC, would be greatly affected by such a move, as more than 40 per cent of its annual budget goes to support the development of nuclear power, much of it $¥ 160$ billion (US $\$ 1.4$ billion) 一 to PNC.

Calls for reform from the top levels of Japanese government came after the revelation this month that PNC officials had falsified reports about a fire and explosion in March at a facility used for the 'bitumenization' of lowlevel radioactive waste in Tokai, northeast of Tokyo (see Nature 386, 209; 1997).

Responding to pressure from the police, the STA has filed a criminal complaint against the organization, as well as against PNC officials who tried to cover up a false report to the agency claiming that the fire had been extinguished shortly after it started. In fact, the waste facility blew up ten hours after the fire was reported to have been extinguished.

Three days before the STA filed its complaint, a minor leak of heavy water and tritium gas occurred at another PNC facility, the Fugen advanced thermal reactor in Fukui Prefecture on the Japan Sea coast. PNC took 30 hours to report the leak to the agency and local government. It has since been revealed that similar leaks have occurred on 18 previous occasions since 1992. But none was reported by $\mathrm{PNC}$, despite an agreement with the local government to do so.

The STA has accepted that no laws were broken at Fugen. But the agency has shut down the reactor to make its operators aware of what Kaname Ikeda, director-general of STA's nuclear safety bureau, calls their "moral and social" obligation to report leaks.

The Fugen and Tokai incidents follow a leak of sodium coolant at PNC's Monju fast-breeder reactor in December 1995. PNC officials attempted to hide a videotape recorded shortly after that leak (see Nature 379, 196; 1996). With three of its key facilities closed down, PNC is crippled.

Japan's prime minister, Ryutaro Hashimoto, has been repeatedly questioned by the media about PNC, and is exasperated by its failings. Seiroku Kajiyama, chief cabinet secretary, has called for a review of PNC with "nothing offlimits", including its "dissolution if that is what is needed".

Last Friday (18 April), the STA hurriedly
Covering up: An official puts on protective gear to tackle the accident at the Tokai nuclear plant.

convened a PNC reform committee of nine academics and industrialists headed by Horiyuki Yoshikawa, former president of Tokyo University. Ikeda says the committee has been told by Riichiro Chikaoka, the cabinet member who heads the STA, to consider "all options". These include privatization, partial privatization, reorganization under the government and dissolution.

But the private sector has expressed little interest in taking over PNC, apart from its demonstration nuclear fuel enrichment facility in Ningyo-Toge in Okayama Prefecture and its fuel reprocessing and fabrication facilities in Tokai, which are already run on a commercial basis.

Hashimoto is said to be sceptical about total privatization and believes that the research and development components of the organization should remain in the government domain. One possibility is that PNC will be carved up, with part of its responsibilities being transferred to the Atomic Energy Research Institute, also overseen by the STA and located in Tokai.

Ikeda expects the committee to reach a conclusion in only a few months because the reform of PNC is likely to become part of the government's much bigger proposed administrative reform of ministries and agencies. That reform is expected to be formulated by the end of September, when there will be an election for leadership of the ruling Liberal Democratic party.

Although the STA has been rocked by the PNC scandal, some observers think it could have positive ramifications for other research supported by the agency. It could drive the STA to divert more funds to non-nuclear research, such as the life sciences. This trend is already occurring with the agency's recent large investments in brain research and limited increases in the budget for nuclear power (see Nature 383, 7; 1995). DavidSwinbanks 